\title{
Knowing of Madurese Culture: The Tradition of Ulem-Ulem and Siaran in a Wedding Party
}

\author{
Fajar Surya Hutama ${ }^{1}$, Zetti Finali², Nabila Cahya Bulan ${ }^{3}$, Mareta Alif \\ Arifiyanti $^{4}$, Dyah Ayu Puspitaningrum ${ }^{5}$, Yuni Fitriyah Ningsih ${ }^{6}$, Fitria \\ Kurniasih $^{7}$
}

\author{
${ }^{1}$ Elementary Education Study Program, University of Jember, Indonesia \\ Email: fajarsurya.fkip@unej.ac.id \\ ${ }^{2}$ Elementary Education Study Program, University of Jember, Indonesia \\ Email: zettifinali.fkip@unej.ac.id \\ ${ }^{3}$ Elementary Education Study Program, University of Jember, Indonesia \\ Email: wulan28bulan@gmail.com \\ ${ }^{4}$ Elementary Education Study Program, University of Jember, Indonesia \\ Email: maretaalif@gmail.com \\ ${ }^{5}$ Elementary Education Study Program, University of Jember, Indonesia \\ Email: dyahayu.fkip@unej.ac.id \\ ${ }^{6}$ Elementary Education Study Program, University of Jember, Indonesia \\ Email: yunifitriyah.fkip@unej.ac.id \\ ${ }^{7}$ Elementary Education Study Program, University of Jember, Indonesia \\ Email: fitria.fkip@unej.ac.id
}

\begin{abstract}
The tradition of ulem-ulem and siaran in a wedding party are unique and exciting traditions, because it uses cigarettes, soaps, and laundry detergents to invite many people to attend a wedding party. This research aims to describe: (1) the process and implementation of the tradition ofulem-ulem and siaran in a wedding party; and (2) the positive and negative impacts of the tradition of ulem-ulem and siaran in a wedding party. The type of this research is descriptive qualitative which the methods of the data collection are interview and documentation. The analysis used is qualitative descriptive analysis in a narrative form. The results of this research show: (1) The tradition of ulem-ulem is sharing invitation cards around two weeks before a wedding party is held and siaran is done when a wedding party is in progress. (2) The tradition of ulem-ulem and siaran have both positive and negative impacts. One of the positive impacts is many guests bringing gifts. And one of the negative impacts is disturbing many people when they are all sleeping at night.
\end{abstract}

Keywords - The tradition of ulem-ulem1; the tradition of siaran2; and a wedding party3.

\section{INTRODUCTION}

Indonesia is a multicultural country that having power of the islands, ethnic groups, local languages, and religions. At 21 centuries that ongoing of the globalization era, most of Indonesian people show interested with the different culture in other countries. Based on research students of high school in Manado, they begin to leaving their own culture as a handle of life and imitated Korean pop culture from television. Moreover, they agree to wasted many times for getting information about foreign culture (Karapang, 2013: 1). In this case is manifested of mutation culture and it was to threat indigenous culture. According to this reason, it's very important to publish and giving more information about our culture.

The cultural diversity existing in Indonesia becomes a special attraction which distinguishes Indonesia from other countries. According to Mead (in Sutarno, 2008: 14 ), culture is a behavior learned in a society or sub group. Also, the cultural diversity existing in Indonesia has created various cultural diversities. One of them is a way to celebrate wedding party in all of regions of Indonesia which generally has a uniqueness and typical thing. The uniqueness and typical thing makes the exotic of national culture be incredible and interesting to know. Cermee village society still carries out unique tradition in a wedding party and decided always protected. Cermee village located in the Cermee subdistrict Bondowoso regency, East Java.

Cermee village society believed that a wedding party must be held with merry. It can make a good impression and be reminded of our memory as happiness forever. Marriage is a physic and mental relationship between a man and woman to qualify requirements and pillars 
determined by Islamic law (Sholikhin, 2010: 179). Marriage is a physic and mental relationship between a man and woman as a couple which aims to make a happy and harmonious family (Manan, 2002: 11). It is so related to religion. Marriage is not only about physical thing, but also spiritual thing. Marriage is so important for human life, because it includes elements of one's right and obligation related to family life which has to be completed. It is either husband and wife's right and obligation or marriage status, children, wealth, inheritance, and demographic factors in social life (Kamal, 2014: 35). Marriage is a relationship between a husband and wife having a family and create a social relationship (Prodjodikuro in Soegianto, 2003: 46). Wedding party in Cermee village society is very important to do because it can make huge happiness for all people.

In this wedding traditions hoped many people can giving support the couple by materials and morals to start their happy life as a wife and a husband. The tradition comes from Latin: traditio, which means "continued" or habit. In very simple definition, it means something which has been done for a long time and become part of social life. Tradition is a custom which inherited by ancestor which is still applied in social life. Also, it's believed that something which has existed already is correct (KBBI 2008: 1728). Tradition means continuous activities from generation to generation which is either written or spoken. Tradition is a custom which inherited from generation to generation which is still applied in social life. Our ancestors certainly want the next generations to keep their heritage. It can be material and non-material. Some belonging to material heritages are paintings, sculptures, and statues. And some belonging to non-material heritages are languages, dialects, ceremonies, and norms. Traditions applied by some people aims to make others know anything related to cultures and historical values. Also, tradition will be able to create a harmonious life. However, it will happen only if people can appreciate, respect, and run a tradition properly and obey the rule applied in social life.

Tradition among some regions certainly have many differences, although there are some traditions having similarities. A tradition which is unique and interesting to know is tradition of ulem-ulem and siaran in wedding party. Ulem-ulem comes from the word ulem which the meaning is "to invite" in Sanskrit. Also, the wedding party completed with announcing some gifts brought by the guests. After that, people who have been invited will attend the wedding party bringing some gifts for the couple and family. The tradition of Siaran is often done by people from Madura. The tradition of Ulem-ulem and Siaran is so unique, because it is only held in Cermee village. Ulem-ulem is usually made of paper. It is unlike ulem-ulem in Cermee village which related to inviting people, sharing cigarettes, soaps, and laundry detergents. This tradition has been deeply embedded in society. The tradition of Ulem-ulem and siaran is also implemented in the other events, such as in circumcision ceremony, but it is more dominant applied in wedding party.

The tradition of the siaran is made during a wedding party. Everyone who attending the wedding party must bring gifts for the couple. It can be money, rice, sugar, etc. Then it will be informed by using loudspeaker. Immigrants who live in Cermee village assume that they get some disadvantages, when the tradition is held.

Cermee village society believed that tradition ulem-ulem and siaran can make tighten of relationship and harmonious in life. This tradition also giving benefits for many people, ulem-ulem as goods are very useful and gifts from guests are giving decrease cost of wedding party also to be the financial capital for couple. There are so many traditions in Indonesia not yet to know, for example is tradition ulem-ulem and siaran in Cermee village. The local tradition needs to know, in order to make it more popular. The formulation problems of this paper are: (1) How is the tradition of ulem-ulem and siaran in the wedding party located in Cermee village, Bondowoso? ; (2) What are the positive and negative impacts of the tradition of ulem-ulem and siaran for the director and some people living in Cermee village, Bondowoso?

\section{METHODS}

The research method is a scientific way to obtain data used to achieve the goals and determine the answers to the problems presented accurately and systematically. This is used qualitative research method (naturalistic). Qualitative research method is a research procedure that produces descriptive data in the form of words written or spoken of people and behaviors that can be observed (Bogdan \& Tylor in Moleong, 1993: 3).

The qualitative research design used in this study is ethnography. Ethnography has a background in anthropology. The term means "portrait of a people" and it is a methodology for descriptive studies of cultures and peoples. The cultural parameter is that the people under investigation have something in common (Hancock, 2002: 4-5).

A case study is an important type of ethnography. Case study researchers may focus on a program, event, or activity involving individuals rather than a group. Also, when case study writers research a group, they may be more interested in describing the activities of the group instead of identifying shared patterns of behavior exhibited by the group. The ethnographer searches for the 
shared patterns that develop as a group interacts over time. Finally, case study researchers are less likely to identify a cultural theme to examine at the beginning of a study, especially one from anthropology; instead, they focus on an in-depth exploration of the actual "case" (Creswell, 2012: 465).

Case study in this research is applied in some people about the progress and impact of tradition ulem-ulem and siaran in wedding party located in Bondowoso. The type of this research is descriptive qualitative and the data collection methods used are in-depth interviews on informants and documentation.

Interviews were conducted through face to face and question and answer directly, which contains questions about the process of tradition of ulem-ulem and siaran in the wedding party held in Cermee village, Bondowoso, and also the positive and negative impacts for some people living around that village. Interviews were conducted with a number of respondents from some quarters, the local residents who come from families, neighbors, and wedding party guests which are the newcomers (recently moved to the Cermee village). Document used in this research is the note of activities in the wedding party.

\section{RESULTS}

3.1 The process of tradition of Ulem-ulem and Siaran in the wedding party held in Cermee village, Bondowoso

Ulem-ulem in the Madurese language means an invitation. Generally, the invitation given to the people who will be invited to the wedding party is a paper decorated with unique words related to marriage, but in Cermee village, the invitation or what some people is ulem-ulem is share by using cigarettes, soap and laundry detergent with various brands based on to the director desire. Usually, soaps, laundry detergents, and cigarettes chosen is the cheapest. It is done, because other things spend much money. There are two reasons for using soaps or cigarettes in ulem-ulem based on interviews with one informant who is the neighbor of the bride, namely: (1) The value of cigarettes and soaps are higher than paper; (2) It aims to make guests bringing many gifts for the couple as a respect.

Ulem-ulem is usually distributed two weeks before the wedding party. Here is the example of ulem-ulem. $\underline{\text { Ulem-ulem }}$

Day : Tuesday

Date : $20^{\text {th }}$ April 2016

Time : No exact time

Place : Cermee village RT.25

Our regard

Mr.Ferdi

Mrs. Ferdi

Fig.1: Sample Description on Ulem-ulem

After ulem-ulem or invitation is deployed, a day before the day of the wedding party, all is prepared including annotator's places to broadcast. There are three authors, namely: (1) A male annotator is special for male guests; (2) A female annotator is special for female guests; and (3) Broadcasting place is to broadcast the gifts bringing by the guests. There are certain reasons making of the male and female annotator are different. Based on the interviewing Mr. X, who is the family of the bride, the reasons are: (1) to distinguish between a gift of men and women; and (2) to know a number of men and women attending the event. Annotators' book must be prepared with various types. Each annotator has one book.

Here is an example of the annotator's book format:

Table 1. Format Books Authors

\begin{tabular}{|c|c|c|c|c|c|c|c|c|}
\hline Z & 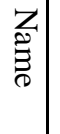 & $\begin{array}{l}\frac{1}{2} \\
\frac{2}{2} \\
0\end{array}$ & 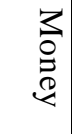 & & $\frac{\overrightarrow{0}}{\vec{\delta}}$ & & $\begin{array}{c}\tilde{\sigma} \\
\tilde{\sigma} \\
\stackrel{\sim}{\approx}\end{array}$ & \\
\hline & & & $\begin{array}{l}\text { Any } \\
\text { ar } \\
(\mathrm{Ne} \\
\mathrm{w})\end{array}$ & $\begin{array}{l}\text { Abeli } \\
h \\
\text { (Back } \\
\text { ) }\end{array}$ & $\begin{array}{l}\text { Anya } \\
r \\
\text { (New } \\
\text { ) }\end{array}$ & $\begin{array}{l}\text { Abe } \\
\text { lih } \\
\text { (Ba } \\
\mathrm{ck})\end{array}$ & $\begin{array}{l}\text { Anya } \\
r \\
\text { (New } \\
\text { ) }\end{array}$ & $\begin{array}{l}\text { Abeli } \\
h \\
\text { (Back } \\
\text { ) }\end{array}$ \\
\hline 1 & $\begin{array}{l}\overrightarrow{0} \\
\vec{\Delta}\end{array}$ & 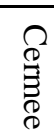 & $\begin{array}{l}500 \\
0\end{array}$ & & $5 \mathrm{~kg}$ & & $10 \mathrm{~kg}$ & \\
\hline 2 & $\begin{array}{l}T \\
\stackrel{2}{*}=\end{array}$ & $\underset{\mathscr{E}}{\mathscr{E}}$ & & $\begin{array}{l}10,00 \\
0\end{array}$ & & $\begin{array}{l}6 \\
\mathrm{~kg}\end{array}$ & & $3 \mathrm{~kg}$ \\
\hline 3 & $\begin{array}{l}\underset{D}{\pi} \\
\frac{\pi}{\partial}\end{array}$ & 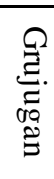 & $\begin{array}{l}500 \\
0\end{array}$ & & $3 \mathrm{~kg}$ & & $5 \mathrm{~kg}$ & \\
\hline
\end{tabular}


After all is ready, the next day which is on the day of the wedding party, the writers are already at their own positions. After the wedding ceremony, the broadcaster will begin with the opening. Broadcasting is done by people who are expert in broadcasting. Some gifts brought by the guests are usually broadcasted by a man. There is a custom before starting broadcasting, the mother of the groom spread "yellow rice". After that, playing Madura music is often called "Agudhung".

After that, the broadcasterstart opening in advance using Madurese language. "Assalamualikum. Wr. Wb sareng nyebut Bismillah kaule atas nyamah toan roma ngator aghi susunan acara edelem karammian nika enggi ka'dhinto penulis lalakek atas nyamah Bapak Syamsul Arifin ben ebhento sareng Bapak Ferdy, saterosepon penulis bebhinik atas nyamah $\mathrm{Bu}$ ' Renny Lestari ben ebhento Bu' Suniye. Saterosepon se kapeng dhue' enggi nika bhegien dhepor umum Bu'Mawati ebhento sareng Bu'Siada, ben se kapeng tello'penerima tamoi langsung epimpin sareng tuan rumah engghi ka'dhinto Bapak Agus sareng Bu'Wiwin. Saka'dhinto susunan acara karammian nika. Wassalmualaikum. Wr. Wb".

When each annotator gets around 20 guests whom gift notes are on the note book, they give it to the broadcasters to inform.

"Sombengan sepertama enggi ka'dhinto dheri Bapak Arni alamat epon Soleng Bherek RT 11 kasokan apareng sombengan beres 5 kilo, obeng sapoloebuh engghi ka'dhinto sombengan anyar. Sombengan senomer dhue' dheri keluarga Bapak Faizal kasokan apareng cacapan dhe'komantan se dhue' aropa aghi sellok soca mera berrek'en dhu gram duratus. Saterosa dheri Bapak Buyadi kasokan ngator aghi sombengan abelihen aropa aghi beres seket kilo, gule sapolo kilo sareng obeng dupoloebhuh". When each annotator gets around 20 guests whom gift notes are on the note book then it is broadcasted. After that, the broadcasters will tell the music operator. "Eyator agi dhe'ka bhegien sound system se e tugasen aghi dhe'kasa'na gebey moter musik".

After it is done, broadcasting is continued. At the end, after all guests name's is informed, it will be informed the total of all gifts which brought by the guests. Broadcasters will broadcast it in Madurese. "se terakhir enggi ka'dhinto pamaparan hasel akhir dheri karamian nika olle obeng tello polo juta, ben berres lema ton lebbi dulekor kilo, sareng gulenah tello ton lebbi seket kilo. Saka'dhinto sombengan se eperoleh sareng tuan romaBapak Agus bedhen kaule atas nama tuan roma ngator aghi sakalangkong se sobung betessa dhe'ka sombengan se ampon eparengaghi. Saterosepon bedhen kaule salako petugas siaran anyoon maap se sobung betesna manabi bede tor ator se korang sopan dhek ka ajunan sedheje. Sekian, wasalamualikum.Wr.Wb".
3.2 Positive and Negative Impact of Tradition Ulemulem and Broadcast on Own Celebration an Environment Society Around Cermee

The tradition of ulem-ulem and siaran has positive and negative impacts for some people.

The positive impacts of the tradition of ulem-ulem and siaran are :

a. Oreng se andhik hajeten lebur ka min rammin, mon tadek siaran aparlo seppe.

b. Mak le reng oreng tao apa se esambhi ben tamuy se entar ka hajetan ria

c. Oreng se namuy mak le benyak bisambienna dhe'ka komantan dhuwe'.

d. Hasille se se eperoleh andhik hajeten paste benyak.

e. Undangan se etabur kan angguy sabon atabe rokok arua makle aghuna.

Besides positive impact, the tradition of ulem-ulem and siaran also has negative impacts in social life. Based on interviews with immigrants in Cermee village. The negative impacts of this tradition include:

a. It burdens some guests. Because if they do not bring many gifts, they will feel embarrassed.

b. It will disturb some people's sleeping time, because it will be done at midnight.

c. It spends much money.

d. If the outcomes obtained are not good, the director will be disappointed.

\section{DISCUSSION}

4.1 The process of tradition of Ulem-ulem and Siaran in the wedding party held in Cermee village, Bondowoso

Wedding party held in Cermee village is always related to the tradition of ulem-ulem and siaran. Ulem-ulem and siaran is held by some people who have long lived for such a long time in Cermee village and is done from generation to generation. Ulem-ulem in the Madurese language means an invitation. Generally, the invitation given to the people who will be invited to the wedding party is a paper decorated with unique words related to marriage, but in Cermee village, the invitation or what some people is ulem-ulem is share by using cigarettes, soap and laundry detergent with various brands based on to the director desire. Usually, soaps, laundry detergents, and cigarettes chosen is the cheapest. It is done, because other things spend much money.

Ulem-ulem is usually distributed two weeks before the wedding party. For example : a wedding party will be held in 20th, April 2016, then ulem-ulem will be distributed between 5th and 7th April 2016. It will not be shared or distributed by the director, but others will do it. For relatives will be invited directly without ulem-ulem. Description of celebration in ulem-ulem include in a 
small piece of paper containing a schedule which is held in no exact time. It means that there is no time limitation, but it usually starts at $7 \mathrm{pm}$. A small piece of paper attached to the soaps and cigarettes. Here is the example of ulem-ulem.

After ulem-ulem or invitation is deployed, a day before the day of the wedding party, all is prepared including annotator's places to broadcast. There are three authors, namely: (1) A male annotator is special for male guests; (2) A female annotator is special for female guests; and (3) Broadcasting place is to broadcast the gifts bringing by the guests. There are certain reasons making of the male and female annotator are different. Based on the interviewing $\mathrm{Mr}$. X, who is the family of the bride, the reasons are: (1) to distinguish between a gift of men and women; and (2) to know a number of men and women attending the event. Annotators' book must be prepared with various types. Each annotator has one book.

After all is ready, the next day which is on the day of the wedding party, the writers are already at their own positions. After the wedding ceremony, the broadcaster will begin with the opening. Broadcasting is done by people who are expert in broadcasting. Some gifts brought by the guests are usually broadcasted by a man. There is a custombefore starting broadcasting, the mother of the groom spread "yellow rice". It has been soaked in turmeric water at house yard in order to invite many people. After that, playing Madura music is often called "Agudhung".

After that, the broadcasterstart opening in advance using Madurese language.

The meaning of the sentence above is told below.

"Assalamualaikum. Wr. Wb, by saying Bismillah, I am on behalf of the host read out the order of events in this wedding party, Mr. Syamsul Arifin's male annotator and assisted by Mr. Ferdy. Also, the woman annotator on behalf of Mrs. Renny Lestari assisted by Ms. Suniye. Then, the second are part of a common kitchen led by Mrs. Mawati assisted by Ms. Siadah, and the third event is the reception directly led by the host, Mr Agus and Mrs. Wiwin. It is all about this wedding party. Wassalamualaikum. Wr. Wb".

When each annotator gets around 20 guests whom gift notes are on the note book, they give it to the broadcasters to inform.

Then the sentence can be interpreted like this below.

"The first donation is from Mr. Arni who lives in Suling Kulon RT 11. He give $5 \mathrm{Kg}$ of rice, Rp 10,000 and is a new contribution. The second donation is from $\mathrm{Mr}$ Faizal's family. The donation is ring weighing 2 grams - Then, It is from Mr. Buyadi. He contributes $50 \mathrm{~kg}$ of rice, $10 \mathrm{~kg}$ of sugar and $\mathrm{Rp} 20,000$ ".
The reasons for broadcasting this one, are: (1) if the guests brings a little, they will be embarrassed (2) Everyone will know how many participants attend; and (3) to know whether the gifts brought by guests are new or not. When each annotator gets around 20 guests whom gift notes are on the note book then it is broadcasted. After that, the broadcasters will tell the music operator. The sentence can be interpreted like this below.

"The music operator is asked to play the music". After it is done, broadcasting is continued. At the end, after all guests name's is informed, it will be informed the total of all gifts which brought by the guests. Those are money, rice, and sugar.

The sentence can be interpreted like this below.

"At the end, it is the exposure of all. It gets thirty million, five-ton of rice, twenty two kilo and three tons of sugar. It is what is got by Mr Agus, I am on behalf of the host would like to thank to the guests who have contributed. Then, I am sorry if I have mistakes indirectly.

Wasalamualaikum.Wr.Wb ".

4.2 Positive and Negative Impact of Tradition Ulemulem and Broadcast on Own Celebration an Environment Society Around Cermee

The tradition of ulem-ulem and siaran has positive and negative impacts for some people. There are some people still applying the tradition of ulem-ulem and siaran but others stop applying it, because of some reasons.

The positive impacts of the tradition of ulem-ulem and siaran are :

a. People who have a celebration, will not get many guests, if there is no broadcast.

b. To let people know what is brought by the guests in wedding party.

c. To make the guests bring many gifts.

d. The outcomes obtained by people who have a celebration is certainly a lot.

e. Invitation on the soaps or cigarettes will be useful.

Besides positive impact, the tradition of ulem-ulem and siaran also has negative impacts in social life. Based on interviews with immigrants in Cermee village. The negative impacts of this tradition include:

a. It burdens some guests. Because if they do not bring many gifts, they will feel embarrassed.

b. It will disturb some people's sleeping time, because it will be done at midnight.

c. It spends much money.

d. If the outcomes obtained are not good, the director will be disappointed.

\section{CONCLUSION}

Based on the discussion which has been done, we can make some conclusions below.

1. The tradition of Ulem-ulem and Siaran are tradition 
kept from generation to generation by people living in Cermee village. Ulem-ulem is an invitation in Madurese which is different from usual invitations. It is always related to cigarettes, soaps and laundry detergents. It is usually shared or distributed two weeks before the wedding party held. It is not shared by the director of wedding party, but other people will help to share it. Siaran is informing what guests bring to the wedding party for the couple. Those are money, rice, sugar, etc. Siaran will end at midnight when the last gift brought by the guests informed.

2. Tradition Ulem-ulem and Siaran have positive and negative impacts for the director of the wedding party and some people, including immigrants living in Cermee village. One of the positive impacts is some people will bring a lot of gifts. And one of the negative impacts is disturbing some people's sleeping time.

\section{ACKNOWLEDGEMENTS}

Thanks to Prof. Dr. Suratno, M.Si. and Prof. Drs. Dafik, M.Sc., Ph.D from the University of Jember also Drs. Nuriman, Ph.D as reviewer for his insightful comments on an earlier draft of this article.

\section{REFERENCES}

[1] Creswell, John W. 2012. Educational Research : Planning, Conducting, and Evaluating Quantitative and Qualitative Research. Pearson Education, Inc. Boylston Street, Boston, MA. 4th ed.

[2] Hancock, Beverley. 2002. Trent Focus for Research and Development in Primary Health Care: An Introduction to Qualitative Research. Trent Focus, 1998.

[3] Kamal, F. 2014. Jurnal Khasanah Ilmu. Perkawinan Adat Jawa dalam Kebudayaan Indonesia. Vol.V, 35, 35-46.

[4] Karapang, O. 2013. Jurnal Acta Diurna. Analisa Gaya Hidup Remaja dalam Mengimitasi Budaya Pop Korea melalui Televisi. Vol.II, 2, 1-15.

[5] Manan, A. 2002. Pokok-pokok Hukum Perdata Wewenang Pengadilan Agama. Jakarta: Raja Grafindo Persada.

[6] Moleong, Lexy. 1993. Metodologi Penelitian Kualitatif. Bandung: Remaja Rosda Karya.

[7] Nasution, S. 2012. Metode Research (Penelitian Ilmiah). Jakarta: Bumi Aksara.

[8] Sholikhin, M. 2010. Ritual dan Tradisi Islam Jawa. Yogyakarta: Narasi.

[9] Soegianto. 2003. Kepercayaan, Magis, dan Tradisi dalam Masyarakat Madura. Jember: Tapal Kuda.
[10] Sutarno. 2008. Pendidikan Multikultural. Jakarta: Departemen Jendral Pendidikan Tinggi Departemen Pendidikan Nasional. 